\title{
Pemberdayaan Masyarakat dalam Pengurangan Risiko Bencana Banjir di Kecamatan Padang Selatan
}

\author{
Triana Anggun ${ }^{1}$, Roni Ekha Putera ${ }^{1}$, dan Roza Liesmana ${ }^{1}$ \\ Jurusan Administrasi Publik, Fakultas Ilmu Sosial dan Ilmu Politik, Universitas Andalas
}

\begin{abstract}
In order to increase community roles in disaster management, the Padang City government facilitated the formation of the Disaster Preparedness Group (KSB). Padang Selatan Subdistrict is one of the regions that conducts community empowerment activities, the phenomenon of which is a region that has a high level of vulnerability. The purpose of this research is to explain and describe the process of community empowerment in flood disaster risk reduction in Padang Selatan Subdistrict. Based on the results of the research, conclusions can be drawn about community empowerment carried out by the Padang City BPBD and Padang Selatan District KSB. However, the empowerment carried out has not been optimal, this is due to the high level of community dependence and the duties of the KSB Sub-District of Padang which are not yet clear in carrying out community empowerment. The suggestions that can be conveyed are: training and outreach should be carried out in an equitable and sustainable manner, as well as clarify the KSB duties and functions so that activities related to disaster can be carried out properly by all members.
\end{abstract}

Keywords: Community Empowerment, Disaster Risk Reduction, Padang Selatan District

\section{Pendahuluan}

Indonesia merupakan salah satu negara yang risiko ancaman terhadap bencana cukup tinggi, baik itu becana gempa bumi, tsunami, banjir, tanah longsor, kebakaran dan lainnya ini disebabkan secara geografis wilayah Indonesia berada diantara lempengan besar IndoAustralia dan Eurasia (Anwas, 2013).

Pentingnya masyarakat dalam penanggulangan bencana telah dijadikan kesepakatan bangsa Indonesia yang tertuang dalam Undang Undang Nomor 24 Tahun
2007 Pasal 16 ayat (3) ditegaskan bahwa kegiatan kesiapsiagaan merupakan tanggung jawab pemerintah, pemerintah daerah, dan dilaksanakan bersama-sama masyarakat, dan lembaga usaha. Sebagai upaya penanggulangan bencana secara menyeluruh (comprehensif), masyarakat telah dijadikan sebagai salah satu unsur terpenting.

$$
\text { Data Badan Nasional }
$$

Penanggulangan Bencana (BNPB) dalam Indeks Rawan Bencana Tahun 2017 menyebutkan bahwa Kota 
Padang termasuk tiga Ibukota Provinsi yang memiliki tingkat resiko bencana tinggi terbanyak, yaitu empat jenis bencana sekaligus diantaranya gempa bumi, tsunami, banjir, dan longsor. Pada 2013, Kota Padang termasuk dalam kategori rentan terhadap bencana, dan peringkat ke-10 di tingkat nasional dan nomor 1 diantara kabupaten/kota di Sumatera Barat (BNPB)(Putera, Nurasa, \& Suganda, 2016).

Penanggulangan bencana telah diatur dalam Peraturan Daerah Kota Padang Nomor 3 Tahun 2008 tentang Penanggulangan Bencana yang meliputi beberapa tahapan diantaranya : pra-bencana, saat tanggap darurat dan pasca bencana. Bahaya bencana dapat dicegah dengan adanya penyadaran dan kewaspadaan dari awal sebelum bencana terjadi (pra-bencana). Dengan demikian, tidak banyaknya kerugian yang dialami masyarakat dan korban berjatuhan yang diakibatkan bencana. Maka, perlu adanya pengurangan risiko bencana pada tahap pra-bencana.

BPBD merupakan leading sector dalam penanggulangan bencana, yang hendaknya memiliki kontribusi yang positif dalam mewujudkan ketangguhan masyarakat dalam menghadapi bencana. Tetapi mencegah dan menggulangi bencana banjir tidak dapat dilakukan pemerintah saja atau orang perorang. BPBD membentuk sebuah kelompok masyarakat yaitu Kelompok Siaga Becana (KSB) yang bertugas membantu pemerintah dalam pelaksanaan pengurangan risiko bencana.
Kecamatan Padang Selatan merupakan daerah yang sering terjadi bencana banjir, yang mana setiap tahunnya terjadi peningkatan kejadian bencana banjir.Dengan demikian, penanggulangan banjir tentu saja dibutuhkan oleh masyarakat. mengingat dampak banjir terhadap masyarakat tidak hanya berupa kerugian harta benda dan bangunan, selain itu banjir juga sangat mempengaruhi perekonomian masyarakat dan pembangunan masyarakat secara keseluruhan terutama pendidikan dan kesehatan.

Pemberdayaan masyarakat menjadi salah satu upaya penanggulangan bencana yang dilakukan BPBD Kota Padang dan di bantu oleh KSB Kecamatan Padang Selatan. Pelatihan dan sosialisasi merupakan bentuk pemberdayaan yang telah dilakukan BPBD dan KSB. Namun, pada kenyataannya dilapangan pemberdayaan yang dilakukan belum berjalan secara optimal. Hal ini disebabkan karena tidak semua masyarakat dapat mengikuti atau menerima pelatihan dan sosialisasi sebagai bentuk pemberdayaan yang dilakukan BPBD Kota Padang dan Kecamatan Padang Selatan.

Oleh karena itu, berdasarkan fenomena tersebut peneliti akan mendeskripsikan dan menjelaskan proses pemberdayaan masyarakat dalam pengurangan risiko bencana banjir di Kecamatan Padang Selatan.

Studi pemberdayaan sebelumnya telah dilakukan Riau Sujarwani dkk (Sujarwani, Wulandari, Husni, \& Rianto, 2018) yang melihat program pemberdayaan komunitas adat terpencil Desa Tajur Biru Kabupaten Lingga. Roni Eka Putera 
(Putera, 2007) yang melihat analisis terhadap program-progam penanggulangan kemiskinan dan pemberdayaan masyarakat di Indonesia. Sementara itu, penelitian oleh Roni Ekha Putera dkk (Putera, Nurasa, \& Suganda, 2019) menyimpulkan bahwa implementasi kebijakan manajemen gempa berbasis bencana mitigasi di Padang belum efektif karena kurangnya pemahaman dan koordinasi antara kebijakan dengan pelaksana dilapangan. Sedangkan studi ini ingin melihat bagaimana proses pemberdayaan masyarakat dalam pengurangan risko bencana banjir di Kecamatan Padang Selatan.

Pemberdayaan masyarakat dalam penanggulangan bencana merupakan salah satu hal yang sangat penting, dengan melakukan pemberdayaan yang tepat kepada masyarakat dapat meningkatkan kapasitas organisasi pemerintah dan lembaga.

\section{Menurut Parsons} pemberdayaan menekankan bahwa orang memperoleh keterampilan, pengetahuan dan kekuasaan yang cukup untuk mempengaruhi kehidupan orang lain yang menjadi perhatiannya. Selanjutnya menurut Ife pemberdayaan adalah menyiapkan kepada masyarakat berupa sumber daya, kesempatan, pengetahuan dan keahlian untuk meningkatkan kapasitas diri masyarakat didalam menentukan masa depan mereka, serta berpartisipasi dan mempengaruhi kehidupan dalam komunitas masyarakat itu sendiri (Anwas, 2013).

Dengan demikian, pemberdayaan merupakan proses meningkatkan kemampuan individu atau masyarakat untuk berdaya yang dilakukan secara demokratis agar mampu membangun diri dan lingkungannya dalam meningkatkan kualitas kehidupannya sehingga mampu hidup mandiri dan sejahtera.

Menurut Shaluf, manajemen bencana didefinisikan sebagai istilah kolektif yang mencakup semua aspek perencanaan untuk merespon bencana, termasuk kegiatan-kegiatan sebelum bencana, dan setelah bencana yang mungkin juga merujuk pada manajemen risiko dan konsekuensi bencana (Kusumasari, 2004). Manajemen bencana (disaster management) adalah ilmu pengetahuan yang mempelajari bencana beserta segala aspek yang berkaitan dengan bencana, terutama risiko bencana dan bagaimana mengindari risiko bencana.

\section{B. METODE PENELITIAN}

Penelitian ini menggunakan metode kualitatif, dengan pendekatan deskriptif (John W. Creswell, 2016). Data yang digunakan adalah primer (wawancara) dan sekunder (dokumentasi). Teknik pemilihan informan dalam penelitian ini adalah purposive sampling yaitu camat Padang Selatan, Lurah Padang Selatan, Kelompok Siaga Bencana Padang Selatan, Masyarakat. Analisis data dalam penelitian kualitatif akan berlangsung bersamaan dengan bagian-bagian lain dari pengembangan penelitian kualitatif, yaitu pengumpulan data mengenai penanggulangan resiko bencana banjir dan penulisan temuan (Neuman, 2017). 


\section{Hasil dan Pembahasan \\ Pemberdayaan Sebagai Proses Pembelajaran}

Proses
masyarakat yang bemberdayaan
mewujudkan perubahan adalah
terwujudnya proses belajar yang
mandiri untuk terus menerus
melakukan perubahan. Dengan kata
lain, dalam setiap upaya
pemberdayaan harus terkandung
upaya-upaya pembelajaran atau
penyelenggaran pelatihan.

Keberhasilan dalam pemberdayaan sebagai proses dapat dilihat dari indikator berikut :

1. Menumbuhkan Kesadaran Masyarakat

Menumbuhkan kesadaran masyarakat dilakukan bertujuan untuk menyiapkan masyarakat untuk memiliki perilaku siaga dan mampu menyikapi bencana yang akan terjadi. Seluruh masyarakat di Kecamatan Padang Selatan merupakan sasaran dilakukannya penyadaran terhadap bencana, sedangkan pelaku dalam menumbuhkan kesadaran masyarakat adalah BPBD Kota Padang dan KSB Kecamatan Padang Selatan.

Dalam menumbuhkan kesadaran terkait bencana bagi masyarakat, maka BPBD Kota Padang dan KSB Kecamatan Padang Selatan melakukan sosialisasi kepada masyarakat. Berdasarkan wawancara, sosialisasi yang dilakukan bertujuan untuk menyadarkan masyarakat bahwa dampak dari bencana banjir yang terjadi dapat di minimalisir. Akan tetapi, temuan dilapangan menunjukan bahwa sosialisasi yang dilakukan tidak terjadwal dan sosialisasi yang dilakukan secara door to door dengan datang kerumah rumah masyarakat. Sehingga hal ini menyebabkan tidak semua masyarakat dapat terjangkau oleh KSB Kecamatan Padang Selatan sebagai relawan yang berkerja secara sukarela tanpa ada digaji oleh pemerintah.

Dengan demikan, dapat dikatakan pemberdayaan yang dilakukan belum berhasil menumbuhkan kesadaran masyarakat mengingat sosialisasi yang dilakukan tidak merata dan bencana banjirpun masih terjadi didaerah tersebut.

2. Peningkatan Pengetahuan Masyarakat

Pengetahuan dapat diperoleh melalui banyaknya mempelajari, banyak mencoba dan banyak menulis. Pengetahuan mengenai kebencanaan akan dibutuhkan masyarakat yang tinggal didaerah rawan bencana, karena berbagai informasi mengenai jenis bencana yang dapat mengancam mereka, gejala-gejala bencana, perkiraan daerah jangkauan bencana, prosedur penyelamatan diri, tempat yang disarankan untuk mengungsi, dan informasi lain yang mungkin dibutuhkan masyarakat pada sebelum, saat, dan pasca bencana itu dapat meminimalkan risiko bencana.

Informasi yang diberikan oleh BPBD dan KSB bertujuan untuk memberikan wawasan pengetahuan kepada masyarakat, agar masyarakat dapat mengetahui bagaimana cara menyelamatkan diri dan keluarga dalam menghadapi bencana, mengetahui apa yang harus dilakukan pada saat terjadinya bencana. Dengan adanya informasi ini, masyarakat akan bertambah pengalamannya sehingga dapat dijadikan pedoman atau acuan bagi masyarakat dalam 
menyikapi bencana yang akan terjadi kedepannya.

Bentuk dari pemberdayaan yang dilakukan adalah pelatihan yang diberikan kepada masyarakat. Akan tetapi, temuan dilapangan menunjukan bahwa kurangnya keseriusan pemerintah dan KSB Kecamatan Padang Selatan untuk menangani permasalahn banjir ini. Berdasarkan hasil wawancara, bencana banjir belum menjadi prioritas utama bagi BPBD Kota Padang dalam penggulangannya. Hal ini dikarenakan setiap tahunnya anggaran yang mereka miliki selalu berkurang dari APBD. Sehingga pelatihan yang dilakukan hanya terfokus kepada bencana yang gempa bumi, yang mana bencana ini merupakan bencana yang tidak diketahui kapan datangnya.

\section{Pemberdayaan sebagai proses penguatan kapasitas}

Kapasitas

merupakan

Kapasitas merupakan sumberdaya atau kemampuan yang dimiliki oleh individu, kelompok ataupun lembaga sabagai upaya kesiapan, pencagahan dan pengurangan risiko bencana. Upaya pemberdayaan masyarakat perlu mengikutsertakan poetensi yang ada pada masyarakat. Dalam hal ini, pemerintah memiliki peranan yang cukup penting dalam pelaksanaan sosialisasi dan pelatihan yang dilakukan dalam upaya pemberdayaan masyarakat bertujuan untuk mengurangi risiko bencana banjir yang terjadi.

1. Penguatan Kapasitas Individu

Pengembangan kapasitas individu, adalah segala upaya untuk memperbaiki atau mengembangkan mutu karakteristik pribadi agar lebih baik(Totok Mardikanto \& Poerwoko
Soebiato, 2017). Dalam pengembangan kapasitas individu diharapkan masyarakat dapat memiliki jiwa yang kreatif yaitu memiliki kemandirian dalam hal penanggulangan bencana tanpa harus adanya intruksi khusus dari BPBD Kota Padang dan KSB Kecamatan Padang Selatan. Untuk itu perlu adanya kecakapan keterampilan yang diperlukan sehingga masyarakat dapat membentuk kemandirian.

Kecakapan keterampilan sangat penting bagi masyarakat, agar risiko bencana yang terjadi dapat di minimalisir. Dengan dilakukannya sosialisasi dapat memberikan manfaat yang besar bagi masyarakat. Masyarakat menjadi tahu apa yang harus dilakukaan saat terjadinya bencana banjir, dengan demikian pengetahuan masyarakat menjadi bertambah dalam menghadapi bencana banjir. Akan tetapi, berdasarkan wawancara masyarakat merasa sudah tidak membutuhkan lagi sosialisasi karna masyarakat juga sudah terbiasa dengan adanya bencana banjir yang sering terjadi. Harapan yang di inginkan masyarakat adalah adanya pelatihan secara berkelanjutan sehingga masyarakat dapat memiliki keterampilan dalam menghadapi bencana banjir yang terjadi.

Namun, pelatihan yang dilakukan juga belum dilakukan secara maksimal dan berkelanjutan sehingga hal ini menyebabkan peningkatan kecakapan keterampilan masyarakat atau peningkatan kapasitas individu belumlah tercapai secara maksimal. Hal ini terlihat, bahwa masyarakat belum mampu dan mandiri untuk menangani dan 
menghadapi jika bencana terjadi terkhususnya banjir.

2. Penguatan Kapasitas Kelembagaan Berbeda dengan pengembangan kapasitas individu, pengembangan kapasitas organisasi lebih ditekankan kepada mutu dari organisasi tersebut, seperti : kejalasan visi dan misi organisasi, kejelasan struktur organisasi, proses organisasi, pengembangan jumlah dan mutu sumberdaya, interaksi antar individu, serta interaksi antara lembaga organisasi dengan pemangku kepentingan(Totok Mardikanto \& Poerwoko Soebiato, 2017).

Kecamatan Padang Selatan mengeluarkan SK Camat Padang Selatan Nomor 48 Tahun 2017 tentang Pengurus Forum Kelompok Siaga Bencana (FKSB) Kecamatan Padang Selatan Periode 2017-2020. Dalam SK tersebut telah ditetapkan nama pengurus FKSB yang nantinya akan melakukan upaya penanggulangan bencana yang terjadi di Kecamatan Padang Selatan. Namun, yang peneliti temukan adalah tidak adanya kejelasan tugas dan fungsi dari KSB tersebut, sedangkan pada SK telah tertulis nama dan jabatan dari pengurus FKSB. Hal ini mengakibatkan dalam pembentukan nama pengurus KSB tersebut hanya formalitas saja.

$\begin{array}{ccc}\begin{array}{c}\text { Dengan } \\ \text { dikatakan }\end{array} & \begin{array}{c}\text { demikian } \\ \text { bahwa }\end{array} & \begin{array}{c}\text { dapat } \\ \text { dalam }\end{array}\end{array}$
pembentukan pengurus dan jabatan KSB ini, tidak adanya tugas dan fungsi yang jelas dalam melakukan upaya penanggulangan bencana. Tidak hanya itu saja KSB juga tidak memiliki Standar Operasional Prosedur (SOP) yang jelas. Sehingga hal ini menyebabkan relawan KSB tersebut tidak dapat di organisir dan tidak profesional dalam melaksanakan tugas sesuai dengan jabatan yang telah tercantum di SK Camat Padang Selatan.

\section{Pemberdayaan sebagai Proses Perubahan Sosial}

Manusia pada hakikatnya selalu menginginkan perubahan, begitu juga dengan BPBD dan KSB yang menginginkan perubahan bagi masyarakat terkait penanggulangan bencana. Bentuk-bentuk upaya penganggulangan bencana dalam pemberdayaan masyarakat, harapannya dapat mengurangi besarnya ancaman dan risiko bencana yang akan diterima oleh masyarakat. BPBD Kota Padang dan KSB Kecamatan Padang Selatan dalam hal ini mengupayakan penanggulangan bencana yang terjadi di Kecamatan Padang Selatan. Ada dua faktor yang dapat mempengaruhi perubahan sosial yang terjadi pada suatu masyarakat :

1. Faktor Geografis

Faktor ini berkaitan dengan lingkungan fisik yang mempengaruhi penduduk untuk mudah atau sulit untuk mengalami perubahan. Umumnya sungai besar dan kecil di Kota Padang ketinggiannya tidak jauh berbeda dengan tinggi permukaan laut. Kondisi ini mengakibatkan cukup banyak bagian wilayah di Kota Padang yang rawan terhadap banjir. Hal ini didukung lagi bahwa Kota Padang merupakan daerah tropis mempunyai curah hujan yang cukup tinggi rata-rata $3583 \mathrm{~mm} /$ th dengan rata-rata hari hujan 16 hari perbulan(Putra, Triyatno, \& Husrin, 2013). 
Kecamatan Padang Selatan sendiri banjir disebabkan oleh topografi wilayah, yang mana wilayah tersebut merupakan wilayah yang berdekatan dengan pebukitan dan wilayah tersebut juga merupakan dataran yang rendah dan rawa, sehingga jika terjadi hujan yang cukup lama maka banjir pun akan terjadi. Selain itu, banjir yang terjadi di Kecamatan Padang Selatan disebabkan oleh ulah masyarakat yang sering membuang sampah di saluran drainase, pendangkalan serta penutupan drainase oleh bangunan sehingga ini dapat mengurangi daya tampung air yang mana jika terjadi hujan akan dipastikan air tersebut meluap dan terjadilah banjir.

Kecamatan Padang Selatan merupakan daerah yang cekungan maka, untuk mengurangi dampak dari risiko bencana banjir terjadi kita perlu beberapa upaya salah satunya dengan memberikan sosialisasi kepada masyarakat agar tidak membuang sampah lagi di drainase dan tidak mempersempit drainase dengan menutup bangunan pemukiman masyarakat. Namun, nampaknya masyarakat enggan untuk mengindahkan arahan yang telah dilakukan oleh BPBD dan KSB Kecamatan Padang Selatan.

2. Faktor Teknologis

Integrasi dalam berbagai teknologi sangat dibutuhkan untuk membantu upaya penganggulangan bencana sehingga dampak dari risiko bencana yang terjadi dapat diminimalisir, baik itu nyawa ataupun harta dan benda. Faktor teknologi juga berkaitan dengan banyaknya penemuan-penemuan teknologis yang mengakibatkan perubahan sosial dalam masyarakat. Dalam penanggulanganan bencana haruslah memanfaatkan ilmu dan pengetahuan seiring dengan perkembangan zaman secara optimal sehingga dalam upaya pengurungan risiko bencana terjadi akan lebih mudah dan cepat untuk di tanggulangi.

$$
\text { Alternatif penggunaan }
$$

teknologi pengendali banjir merupakan alternatif yang terakhir yang dapat dilakukan dalam penanggulangan bencana banjir setelah memperbaiki sistem drainase yang ada diwilayah tersebut. Selain upaya pengendalian bencana banjir dengan pemanfaatan teknologi, maka pengendalian dari manusia itu sendiri juga sangat diperlukan. Dengan menjaga dan memelihara lingkungan, maka tidak ada dampak yang dapat merugikan baik itu alam ataupun manusia itu sendiri.

Akan tetapi, nampaknya alternatif penggunaan teknologi ini tidak dilakukan oleh BPBD dan KSB yang dikarenakan terbatasnya dana dari BPBD dan KSB itu sendiri. BPBD Kota Padang juga belum mampu melaksanakan fungsinya baik, dalam hal ini BPBD sebenarnya memiliki kewenangan untuk dapat berkoordinasi dengan dinas-dinas lainnya. Seperti Dinas Pekerejaan Umum dan Perumahan Rakyat melalui perencanaan tata ruang dan tata kelola yang baik, tata ruang air yang dimaksud adalah penataan ruang yang memberikan perhatian lebih kepada siklus air agar keseimbangannya terjaga. Pada musim hujan air tidak menimbulkan masalah besar seperti banjir dan begitupun sebaliknya.

Pemberdayaan sebagai Proses Pembangunan Masyarakat 
Gerakan pembangunan yang dilakukan oleh pemerintah untuk memperbaiki keadaan masyarakat seharusnya gerakan ini disertai oleh keikutsertaan masyarakatnya sendiri. Dengan demikian upaya penanggulangan banjir melalui pemberdayaan masyarakat dapat berjalan secara efektif dan efisien.

1. Program yang disusun oleh masyarakat

$$
\text { Upaya penanggulangan }
$$

bencana banjir ini bertujuan untuk mengurangi risiko besarnya kerugian yang ditimbulkan oleh bencana tersebut. Masyarakat sebagai korban dan aktor yang berdekatan dengan sumber bencana diharapkan mampu untuk mengidentifikasi, serta memecahkan permasalahan bencana yang terjadi, sehingga dampak dari risiko bencana banjir tersebut dapat dikurangi.

Berdasarkan wawancara dengan informan dapat dikatakan bahwa pemerintah telah melibatkan masyarakat dalam mengidentifikasi permasalahan bencana banjir yang terjadi yang bertujuan agar BPBD Kota Padang dapat memetakan wilayah mana saja yang rentan akan terjadinya banjir. Akan tetapi, pemerintah tidak melibatkan masyarakat dalam perumusan masalah dan solusi apa yang cocok untuk masyarakat yang terkena dampak bencana tersebut. Sehingga mekanisme yang terjadi adalah program yang telah diberikan tidak sesuai dengan yang dibutuhkan oleh masyarakat sehingga ini mengakibatkan perilaku masyarakat yang belum mandiri dan masih bergantung pada bantuan pemerintah, yang mengakibatkan tujuan dari pemberdayaan masyarakat tidak dapat dilaksanakan secara maksimal.

2. Mampu menjawab kebutuhan dasar masyarakat

Berkaitan dengan program yang disusun oleh masyarakat itu sendiri hendaknya upaya pengurangan risiko bencana banjir ini dapat memberikan solusi atas permasalahan bencana banjir yang terjadi. Sehingga tujuan dan sasaran dari program tersebut mampu memenuhi kebutuhan masyarakat serta mampu mengembangkan kapasitas masyarakat itu sendiri.

Namun, fenomena yang peneliti temukan dilapangan adalah dalam pemberdayaan yang dilakukan BPBD Kota Padang dan Kecamatan Padang Selatan lebih dominan pada kegiatan sosialisasi. Sosialisasi memang perlu dilakukan akan tetapi pelatihan juga perlu dilakukan kepada masyarakat sehingga terciptalah masyarakat yang mandiri dan tidak ketergantungan kepada instansi pemerintah jika terjadi bencana banjir. Harapan masyarakat dengan dilakukannya pelatihan ini dapat meningkatkan kapasitas individu terkait kebencanaan.

3. Mendukung keterlibatan kaum miskin dan kelompok terpinggirkan

Banjir yang melanda daerah rawan bencana sering kali menyebabkan keluarga miskin terpaksa mengalami berbagai hal yang mengancam kelangsungan usaha dan kehidupan sosial mereka. Kompleksitas dari permasalahan tersebut, maka diperlukannya penataan atau perencaan yang matang dalam penanggulangan bencana yang tepat. Pemberdayaan masyarakat sangat 
diperlukan agar masyarakat mampu dan mandiri dalam menghadapi bencana dan mampu meminimalisir risiko bencana yang terjadi. Sehingga korban dari dampak terjadinya banjir juga dapat diminimalisir baik itu harta benda maupun manusia.

Pemberdayaan masyarakat yang dilakukan oleh BPBD Kota Padang dan KSB Kecamatan Padang Selatan dilaksanakan secara keseluruhan tanpa membedakan masyarakat miskin dan terpinggirkan dengan masyarakat biasa. Karena bencana ini terjadi secara keseluruhan semua masyarakat yang berada didaerah rawan banjir terkena dampaknya. Namun, fenomena yang peneliti temukan dilapangan adalah pemberdayaan masyarakat dilakukan secara tidak merata bukan karna adanya perbedaan masyarakat misikin dan masyarakat bisa. Akan tetapi, pemberdayaan yang dilakukan memang tidak dapat menjangkau seluruh masyarakat yang ada di Kecamatan Padang Selatan terkendala akan dana untuk melakukan pemberdayaan tersebut.

4. Dibangun dari sumber daya lokal Masyarakat memiliki posisi yang sangat penting dalam upaya pengurangan risiko bencana banjir. Dengan membentuk KSB Kecamatan Padang Selatan yang beranggotakan masyarakat diwilayah itu sendiri, maka hal ini akan dapat memicu masyarakat untuk dapat lebih peduli lagi akan masalah kebencanaan. Selain itu dengan sumber daya yang ada ini nantinya mampu untuk menyadarkan masyarakat terhadap betapa pentingnya untuk menjaga lingkungan.

\begin{abstract}
Pemberdayaan masyarakat merupakan proses dimana masyarakat menjadi aktor dan penentu dalam kegiatan ini sedangkan instansi pemeritahan menjadi fasilitator, yang mana menfasilitasi masyarakat dalam mengembangkan kemampuan untuk berperan dalam upaya pengurangan risiko bencana banjir bagi diri sendiri dan masyarakat. Sehingga termotivasi untuk mengenal masalah, merencanakan, dan memecahkan masalah sesuai dengan potensi yang dimiliki. Hal ini dapat mengurangi ketergantungan masyarakat kepada instansi pemerintahan yang terkait dalam kebencanaan.

5. Sensitif terhadap nilai-nilai budaya lokal
\end{abstract}

Sikap masyarakat merupakan faktor yang sangat berpengaruh dalam bencana banjir yang terjadi setelah faktor lingkungan. Masyarakat yang cuek terhadap bencana banjir yang terjadi mengakibatkan upaya pengurangan risiko bencana banjir ini mendapatkan sedikit kendala. Masih ditemukannya masyarakat yang membuang sampah pada drainase, sehingga ini menyebabkan drainase tersebut tidak dapat lagi menampung debit air yang melimpah dan menimbulkan genangan banjir.

Upaya pemberdayaan masyarakat telah dilakukan oleh BPBD Kota Padang dan KSB kecamatan Padang Selatan, akan tetapi masyarakat juga sangat berpengaruh dalam pelaksanaan pemberdayaan ini. Jika masyarakat cuek terhadap dampak lingkungan yang ditimbulkan dari membuang sampah maka permasalahan banjir ini tidak akan dapat terselesaikan. 
Budaya gotong royong yang sudah mulai menghilang dari masyarakat, membuat tumpukan sampah dibiarkan begitu saja oleh masyarakat.

6. Memperhatikan dampak lingkungan

Dalam proses pemberdayaan masyarakat yang dilakukan oleh BPBD Kota Padang dan KSB Kecamatan Padang Selatan, masyarakat di sadarkan bahwa mereka berada pada daerah yang rentan dan rawan akan bencana sehingga sewaktu-waktu bencana dapat terjadi. Hal ini disebabkan karena kondisi geografis Kecamatan Padang Selatan yang cendrung dataran rendah yang membuat daerah tersebut sangat mudah untuk digenangi oleh air.

Relokasi merupakan solusi terkahir yang bisa dilakukan jika mengingat daerah tersebut memang merupakan rawan terhadap banjir. jika terjadi hujan yang sangat lama maka daerah tersebut dengan mudahnya digenangi oleh banjir. Akan tetapi, mengingat masyarakat disana bermata pencarian disana maka untuk melakukan relokasi merupakan hal yang akan sulit untuk dilakukan. Sejauh ini hanya upaya pemberdayaan masyarakat yang dilakukan masih berupa sosialisasi dan pelatihan kepada masyarakat, mengingat dampak lingkungan yang ditimbulkan jika tidak dilakukan pemberdayaan. Relokasi juga merupakan hal yang bisa dilakukan agar masyrakat didaerah tersebut tidak lagi merasakan banjir. Namun, upaya tersebut membutuhkan waktu yang cukup lama dan diterima dikalangan masyarakat.

7. Tidak menciptakan ketergantungan
Dengan adanya pemberdayaan yang dilakukan oleh BPBD Kota Padang dan KSB Kecamatan Padang Selatan kepada masyarakat yang diberdayakan, harapannya adalah masyarakat tidak ketergantungan lagi dengan instansi pemerintahan yang terkait. Namun, pada kenyataannya dilapangan masyarakat masih cuek dengan upaya yang telah dilakukan BPBD Kota Padang dan KSB Kecamatan Padang Selatan.

Dinamika yang berkembang dalam masyarakat mengenai bencana masih beranggapan bahwa bencana itu terjadi karena adanya kuasa Tuhan, sehingga hal ini menyebabkan bahwa masyarakat lebih bersifat pasarah dan tidak melakukan upaya pengurangan risiko bencana. Disisi lain faktor geografi kawasan ini juga membuat masyarakat pasrah ketika terjadi bencana banjir.

Jika dilihat dari konsep relawan maka KSB Kecamatan Padang Selatan sekelompok orang yang memiliki kemampuan dalam penanggulangan bencana yang bekerja secara ikhlas untuk kegiatan penanggulangan bencana. Dengan demikian, KSB Kecamatan Padang Selatan juga di tuntut untuk mampu secara mandiri melakukan pemberdayaan kepada masyarakat tanpa menunggu instruksi atau pelatihan yang dilakukan oleh BPBD Kota Padang.

8. Berbagai pihak terlibat (instansi pemerintah, LSM dan swasta lainnya)

BPBD Kota Padang merupakan instansi pemerintahan yang mempunyai kontribusi dalam terwujudnya ketangguhan masyarakat dalam menghadapi bencana, sehingga dapat dipercaya untuk melindungi masyarakat dari 
ancaman bahaya bencana. Namun, mencegah dan menanggulangi bencana banjir ini tidak dapat dilakukan sendiri oleh pemerintah saja. Dibutuhkan komitmen dan kerjasama dengan berbagai pihak untuk menghindari terjadinya bencana banjir. Salah satunya yaitu dengan melibatkan LSM. Namun, dalam kasus ini BPBD Kota Padang hanya mengandalkan KSB Kecamatan yang ada, tidak melibatkan peran LSM yang ada. Hal ini dikarenakan peran LSM belum diperlukan dalam pelaksanaan pengurangan risiko bencana banjir.

Berdasarkan hasil wawancara dengan informan sejauh ini keterlibatan LSM belum dibutuhkan, karena masih bisa di kendalikan oleh BPBD Kota Padang dengan KSB Kecamatana Padang Selatan.

Pemberdayaan sebagai Proses Pengembangan Partisipasi Masyarakat

Partisipasi masyarakat

merupakan perwujudan dari kesadaran dan kepedulian serta tanggung jawab masyarakat terhadap terkait kebencanaan, ini bertujuan untuk memperbaiki perilaku masyarakat bahwa pentingnya pengetahuan tentang bencana karena memang bencana tidak dapat kita hindari akan tetapi dapat kita cegah. Pemberdayaan masyarakat dilakukan dengan harapan agar masyarkat yang tinggal didaerah yang rawan akan banjir akan selalu siap dan siaga serta mandiri dalam menghadapi bencana banjir yang terjadi.

1. Lingkup partisipasi masyarakat dalam pembangunan

Partisipasi masyarakat bukan sekedar keterlibatan masyarakat dalam pembangunan saja. Partisipasi merupakan suatu proses dengan tujuan dalam mencapai tujuan pembangunan. Partisipasi mengandung makna keterlibatan adanya kesadaran untuk berubah, terjadinya proses belajar menuju ke arah perbaikan dan peningkatan kualitas kehidupan yang lebih baik.

Partisipasi masyarakat dalam pembangunan perlu ditumbuhkan melalui dibukanya forum yang memungkinkan masyarakat banyak berpartisipasi langsung didalam proses pengambilan keputusan dalam upaya pengurangan risiko bencana banjir di Kecamatan Padang Selatan. Namun, dalam hal ini BPBD Kota Padang tidak memberikan kesempatan kepada masyarakat untuk dapat berpartisipasi dalam merencanakan hal apa saja yang bisa dilakukan dalam upaya pengurangan risiko bencana banjir di Kecamatan Padang Selatan.

Berdasarkan wawancara peneliti dengan informan, bahwa partisipasi masyarakat masih terbatas pada keikutsertaan dalam pelaksanaan kegiatan yang telah dilakukan BPBD Kota Padang, padahal partisipasi masyarakat tidak hanya diperlukan pada saat pelaksanaan tetapi juga mulai tahapan perencanaan bahkan pengambilan keputusan. Tindakan cepat dan terkoordinasi ditambah dengan pengetahuan yang baik tentang masyarakat dan lingkungan adalah hal terpenting dalam mengurangi dampak banjir pada masyarakat.

2. Bentuk-bentuk partisipasi

Peran masyarakat diperlukan dalam meminimalisasir bencana banjir. Partisipasi masyarakat dalam pencegahan dan penanggulangan 
dampak bencana banjir di Kecamatan Padang Selatan bisa dalam bentuk tidak membuang sampah pada drainase. Dalam hal pencegahan banjir dalam jangka panjang tentunya dengan tidak membuang sampah dan menutup drainase-drainase yang ada, hal ini dapat mengakibatkan pengalihan fungsi drainanse yang tidak mampu menampung debit air jika terjadi hujan.

$$
\text { Kurangnya kesadaran }
$$

masyarakat terhadap pencegahan banjir dapat dilihat dari cara hidup masyarakat yang sebagian besar belum mencerminkan budaya hidup bersih dan sehat. Masyarakat terbiasa untuk membuang sampah di sepanjang aliran sungai dan drainase tanpa perduli terhadap dampaknya, dan kebiasaan masyarakat yang tidak ramah pada lingkungan.

3. Tingkatan partisipasi

Salah satu indikator penting dalam pemberdayaan masyarkat adalah seberapa besar tingkat partisipasi masyarakat dalam upaya pengurangan risiko bencana banjir. Untuk terciptanya suatu keberhasilan dalam pelaksanaan pengurangan risiko benana banjir harus didukung dengan partisipasi masyarakat yang baik. Oleh karena itu, indikator dalam mengevaluasi tingkat partisipasi masyarakat sangat penting dipahami secara benar. Terkait pemberdayaan yang telah dilakukan BPBD Kota Padang hanya dua tingkatan dari partisipasi masyarakat Kecamatan Padang Selatan, yakni menerima manfaat dan melaksanakan kegiatan yang telah direncanakan oleh BPBD Kota Padang.

Peran serta masyarakat diperlukan untuk meminimalisir bencana banjir yang terjadi. Sejauh ini, tingkatan partisipasi di Kecamatan Padang Selatan ada dua yakni penerima manfaat dan pelaksana kegiatan. Penerima manfaat atau sasaran pemberdayaan adalah masyarakat sedangkan pelaksanaa kegiatan merupakan sekelompok masyarakat yang mendapatkan pelatihan dari BPBD Kota Padang untuk memperoleh pengetahuan dan kemampuan yang baik dalam menghadapi banjir dengan efektif. Dan kelompok masyarakat inilah yang nantinya akan menyampaikan pengetahuan dan kemampuan yang mereka dapatkan dari pelatihan kepada masyarakat lainnya atau menerapkannya langsung. Namun pada kenyataannya dilapangan KSB Kecamatan Padang Selatan sebagai kelompok masyarakat yang menerima pelatihan dan sosialisasi dari BPBD Kota Padang belum efektif melakukan pelatihan dan sosialisasi.

4. Masalah-masalah partisipasi

Partisipasi masyarakat dalam upaya pengurangan risiko bencana banjir di Kecamatan Padang Selatan sangat diperlukan untuk membantu pemerintah dalam melaksanakan upaya pengurangan risiko bencana banjir tersebut baik secara langsung ataupyn tidak langsung. Tanpa adanya partisipasi dari masyarakat uapaya pengurangan risiko bencana banjir tidak akan bisa berjalan dengan baik, oleh karena itu masyarakat harus berperan aktif dalam setiap kegiatan yang dilakukan oleh BPBD Kota Padang sebagai instansi pemerintah terkait bencana.

$$
\text { Akan tetapi, pada }
$$

kenyataannya partisipasi masyarakat masih pada keikutsertaan dalam melaksanakan kegiatan-kegiatan 
BPBD Kota Padang. Seharusnya partisipasi tidak hanya diperlukan pada pelaksanaan tetapi, pada tahap perencanaan bahkan pengambilan keputusan. Hal ini dikarenakan masyarakatlah yang mengetahui kebutuhan apa yang mereka perlukan dalam upaya pengurangan risiko bencana banjir yang terjadi di wilayah mereka.

Berdasarkan hasil wawancara dikatakan bahwa partisipasi masyarakat di Kecamatan Padang Selatan masih rendah atau kurang maksimal sebagian besar partisipasi masyarakat hanya sebatas keikutsertaan dalam kegiatan pemberdayaan masyarakat yang dilakukan oleh BPBD Kota Padang. Rendahnya partisipasi masyarakat juga diakibatkan kesadaran masyarakat terhadap lingkungan yang bersih juga masih rendah terlihat dari kepedulian masyarakat terhadap lingkungan yang bersih, maka dalam hal ini perlu dilakukan upaya-upaya agar dapat menghimbau masyarakat untuk peduli terhadap masalah kebersihan lingkungan.

5. Komunikasi pembangunan untuk pengembangan

partisipasi masyarakat

Upaya pengembangan partisipasi masyarakat dalam pembangunan dapat diupayakan melalui kegiatan pemberdayaan masyarakat yang didalam praktiknya dilakukan melalui kegiatan komunikasi pembangunan. Tujuan dari komunikasi pembangunan bukanlah sekedar untuk memasyarakatkan pembangunan dan penyampaian pesan-pesan pembangunan saja, tetapi lebih penting dari itu adalah untuk menumbuhkan, menggerakkan dan memelihara partisipasi masyarakat dalam proses pembangunan(Totok Mardikanto \& Poerwoko Soebiato, 2017). Komunikasi ini lebih diarahkan pada membangun pasrtisipasi aktif masyarakat untuk mampu mengubah perilaku masyarakat ke arah yang lebih sadar akan bencana banjir.

Komunikasi

dalam pembangunan dan pemberdayaan hakikatnya membangun perilaku yang dimulai dengan upaya membangun kesadaran akan potensi dan kebutuhan masyarakat. Selanjutnya ditingkatkan melalui komunikasi yang mengajak untuk aktif dalam kegiatan pemberdayaan. Akan tetapi, pada kenyataannya komunikasi telah dilakukan oleh BPBD Kota Padang dan KSB Kecamatan Padang Selatan melalui sosialisasi belumlah maksimal. Hal ini terbukti dalam melakukan sosialisasi kepada masyarakat KSB Kecamatan Padang Selatan tidak membuka forum agar dapat berdiskusi dengan masyarakat mengenai bencana banjir yang terjadi di wilayah mereka.

Komunikasi dalam pemberdayaan hanya akan efektif apabila dilakukan secara dialogis, namun pada kenyataannya dilapangan BPBD Kota Padang dan KSB Kecamatan Padang Selatan tidak melakukan sosialisasi secara dialogis atau membuka forum khusus mengenai upaya pengurangan risiko bencana banjir yang terjadi di wilayah tersebut. Sosialisasi yang dilakukan hanya berupa kunjungan kerumah masyarakat dan memberikan selebaran brosur yang berisikan tentang bagaimana cara menghadapi bencana banjir dan upaya pengurangan risiko bencana 
banjir yang dapat dilakukan oleh masyarakat. Sehingga hal ini menyebabkan komunikasi yang dilakukan hanya satu arah dari pihak BPBD Kota Padang dan KSB Kecamatan Padang Selatan.

This section consists of results and discussion. Every finding should be supported by sufficient data. Then, research findings should be able to answer the research question or hypothesis stated earlier in the introduction.

\section{Kesimpulan}

Pemberdayaan masyarakat dalam pengurangan risiko bencana banjir di Kecamata Padang Selatan telah dilakukan oleh BPBD Kota Padang dan KSB Kecamatan Padang Selatan. Akan tetapi, fenomena yang ditemukan peneliti dilapangan adalah pemberdayaan masyarakat belum dilakukan secara optimal. Hal ini dikarenakan adanya ketergantungan masyarakat yang masih tinggi pada pada instansi pemerintahan; Kedua, Pelatihan tekait bencana banjir masih belum efektif dilakukan hanya dilakukan satu kali setahun; Ketiga, Tidak adanya SOP serta tupoksi yang jelas dari KSB untuk melakukan pemberdayaan kepada masyarakat; Keempat, Bencana banjir belum menjadi prioritas utama dalam upaya pengurangan risiko bencana yang terjadi di Kota Padang. Hal ini dikarekanan keterbatasan dana yang dimiliki BPBD Kota Padang, dan saat ini yang menjadi prioritas BPBD Kota Padang adalah bencana gempa bumi dan tsunami.

Oleh karena itu, disarankan kepada pemerintah agar dapat lebih serius lagi dalam melakukan pemberdayaan kepada masyarakat., terlebih lagi mengenai bencana banjir yang sering terjadi.

\section{Daftar Referensi}

Anwas, E. O. M. (2013). Pemberdayaan masyarakat di era global. Bandung: Alfabeta.

John W. Creswell. (2016). , Research Design. Yogyakarta: Pustaka Pelajar.

Kusumasari, B. (2004). Manajemen Bencana dan Kapabilitas Pemerintah Lokal. Yogyakarta: Gava Media.

Neuman, W. L. (2017). Social Research Methods: Qualitative and Quantitative Approaches (Seventh). United States of America: Pearson. Retrieved from

http://letrunghieutvu.yolasite.co $\mathrm{m} /$ resources/w-lawrenceneuman-social-researchmethods_-qualitative-andquantitative-approachespearson-education-limited2013.pdf

Putera, R. E. (2007). Analisis terhadap Program-program

Penanggulangan Kemiskinan dan Pemberdayaan Masyarakat di Indonesia. Jurnal Demokrasi, 6(1).

Putera, R. E., Nurasa, H., \& Suganda, S. (2016). Synergizing Stakeholders In Reducing Risk of Earthquake and Tsunami-Disaster in the Most Vulnerable Area. . . International Journal of Administrative Scinence \& Organization, 23(3).

Putera, R. E., Nurasa, H., \& Suganda, S. (2019). The implementation of earthquake management policies (Vol.

030032). 
https://doi.org/10.1063/1.5094

030

Putra, A., Triyatno, \& Husrin, S. (2013). ANALISA BENCANA BANJIR DI KOTA PADANG. In Seminar Sains Atmosfer 2013 (pp. 978-979-1453-73-3). Bandung.

Sujarwani, R., Wulandari, F. D., Husni, A., \& Rianto, F. (2018). Pemberdayaan masyarakat komunitas adat terpencil (kat) oleh pemerintah kabupaten lingga, kepulauan riau, 20(1), 17-31.

Totok Mardikanto, \& Poerwoko Soebiato. (2017). Pemberdayaan Masyarakat dalam Prespektif Kebijakan Publik. Bandung: Alfabeta. 